\title{
QUEEN'S
UNIVERSITY
BELFAST
}

\section{A proposal for a White Paper on Geoethics in Forensic Geology}

Dawson, L. A., Di Maggio, R. M., McKinley, J., Di Capua, G., Peppoloni, S., \& Pringle, J. (2021). A proposal for a White Paper on Geoethics in Forensic Geology. In G. Di Capua, P. T. Bobrowsky, S. W. Kieffer, \& C. Palinkas (Eds.), Geoethics: Status and Future Perspectives (Vol. 508, pp. 115-124). Geological Society, London. https://sp.lyellcollection.org/content/508/1/115

Published in:

Geoethics: Status and Future Perspectives

Document Version:

Peer reviewed version

Queen's University Belfast - Research Portal:

Link to publication record in Queen's University Belfast Research Portal

Publisher rights

Copyright 2021 Geological Society.

\section{General rights}

Copyright for the publications made accessible via the Queen's University Belfast Research Portal is retained by the author(s) and / or other copyright owners and it is a condition of accessing these publications that users recognise and abide by the legal requirements associated with these rights.

Take down policy

The Research Portal is Queen's institutional repository that provides access to Queen's research output. Every effort has been made to ensure that content in the Research Portal does not infringe any person's rights, or applicable UK laws. If you discover content in the Research Portal that you believe breaches copyright or violates any law, please contact openaccess@qub.ac.uk. 


\title{
A proposal for a White Paper on Geoethics in Forensic Geology
}

\author{
Lorna Dawson ${ }^{1,4,7}$, Rosa Maria Di Maggio 2,4,7, Jennifer McKinley,3,4,7, Giuseppe Di Capua ${ }^{5,6,7}$, Silvia \\ Peppoloni ${ }^{5,6,7}$ \& Jamie Pringle $e^{4,8}$
}

1 James Hutton Institute, Aberdeen, UK, AB15 8QH; Treasurer, IUGS - IFG

${ }^{2}$ Geoscienze Forensi Italia ${ }^{\circledR}$; Officer for Europe, IUGS - IFG

${ }^{3}$ School of Natural and Built Environment, Queen's University Belfast, Northern Ireland, UK; Communications Officer, IUGS - IFG

${ }^{4}$ IUGS - Initiative on Forensic Geology - IFG

${ }^{5}$ Istituto Nazionale di Geofisica e Vulcanologia, Rome, Italy

${ }^{6}$ International Association for Promoting Geoethics - IAPG

7 IFG-IAPG Working Group on Geoethics in Forensic Geology

${ }^{8}$ School of Geography, Geology \& Environment, Keele University, Keele, Staffs, UK

\begin{abstract}
This paper details the construction of a White Paper on Geoethics in Forensic Geology. It focuses on forensic geology, although it also relates to the wider sphere of the forensic geosciences. Forensic geology is rapidly evolving to provide assistance in police investigations and in criminal and civil courts with providing scientific advice and evidence, but there also should be associated clear guidelines to benefit both the practitioner and the justice system. Examples of where forensic geology delivers to society in a vital way is required and also where potential malpractice could happen.

The paper discusses where forensic geology should pursue social justice in compliance with current legal systems. In order to achieve this goal, it outlines the main areas that we suggest should be developed within the discipline: the competence of the scientist in forensic geology; creation of best practice guidelines; establishing clear duties of the expert in forensic geology; consideration of ethical aspects in forensic geological activities and ethical aspects in communicating geoscience evidence. When developing geoethics within forensic geology, the following practices were identified as of prime importance: improved standardisation of methods; the use of appropriate methods and/or combination of complementary methods; greater clarity of approach used for the location of areas of interest; collection and recovery of evidence; scene examination and sample collection evaluation of data; construction and appropriate use of databases, background information, documentation, cartography and communicating forensic data; summarising evidence and acknowledgement and consideration of uncertainty and bias. Honesty, integrity, respect, transparency, competence, and reliability are vital for the forensic geoscientist to adhere to. Raising the ethical profile of the forensic geoscience profession aims to pave the way to ensure that forensic geoscientists are empowered now and into the future for serving society: acting responsibly and adopting effective ethical codes is vitally important for a safe society.

This paper highlights the necessity to hold urgent discussions on the ethical and social implications of forensic geology and their potential repercussions on societal justice. Forensic geology is a very useful tool, but like any other tool in human hands, it presupposes responsibility in its application. Professionalism and honesty in forensic geology are fundamental to assure the public that geoscientists involved have the highest scientific respectability, social credibility, and community
\end{abstract}


respect for their role to help pursue judicial truth. The aim of this draft White Paper is to stimulate an open and informed debate on geoethics.

\section{Introduction to a White Paper on Geoethics in Forensic Geology}

This paper stems from an International Union of Geological Sciences (IUGS) meeting held in Vancouver, Canada in 2018, where we proposed and discussed ethical considerations within the field of forensic geology. It outlines a proposal on which to build a White Paper on Geoethics in Forensic Geology, focusing on forensic geology per se, although of relevance to the wider forensic geosciences. Forensic geology is rapidly evolving to provide assistance in police investigations and in criminal and civil courts, and proposes that there should be clear guidelines associated with this discipline.This proposal aims to start this process. The longer term aim is to develop a set of guidelines for practicing geoscientists to refer to, defend and be guided by.

Forensic geology relates to the investigation of minerals, hydrocarbons, metals and other materials found in the Earth (soil, debris, rocks, etc.), and of geological, geomorphological and geophysical features of the environment, used to answer any questions raised by the legal system, often set within the context of criminal law (Murray and Tedrow, 1975; Ruffell \& McKinley, 2005; 2008; Ritz et al., 2009; Bergslien, 2012). It also relates to aspects of engineering geology, of particular importance in civil law. Forensic geology is a field of forensic science fundamental to contributing to issues related to crimes against people, society, the environment, and natural heritage. This application of geology is an area in which the geosciences can face legal aspects related to offences and crimes of various types, and must provide robust scientific approaches based on the most appropriate available technologies and interpretations, whilst also being based on sound ethical principles (Harrison \& Donnelly, 2009; Donnelly, 2010; Dawson et al., 2019).

\section{Definitions}

Forensic is defined as 'Relating to or denoting the application of scientific methods and techniques to the investigation of crime' (from: Oxford English Dictionary). Forensic geology (also known as geoforensics or forensic geoscience) is the application of geology in the context of a legal framework and to criminal investigations (Ruffell, 2010). Forensic geologists may assist the police or law courts in a range of types of crimes to help investigators determine where, how and when a crime occurred or to help search for homicide graves or other objects which have been buried in the ground (Ruffell \& McKinley, 2008). In a law enforcement context, specialist forensic geologists may support investigations in several areas, for example: (a) geological (trace) evidence; (b) search for burials; (c) environmental crimes; and (d) engineering or accident evaluations related to the underlying geology (Donnelly et al., 2009, Larson et al., 2011; Harrison \& Donnelly, 2010; Donnelly et al., 2020).

Geoethics consists of research and reflection on the values, which underpin appropriate behaviours and practices, wherever human activities interact with the Earth system. Geoethics deals with the ethical, social and cultural implications of geoscience knowledge, research, practice, education and communication, and with the social role and responsibility of geoscientists in conducting their activities (Di Capua and Peppoloni, 2019). 


\section{History and court application}

Since Edouard Locard first formulated his exchange principle: "every contact leaves a trace", geoscientists have applied that same principle in the context of geology and soil science and have developed evidence to support the court in many situations (Locard's vision) (Ramsland, 2012). Courts across the world now generally accept Forensic Geology as a valid source of scientific evidence. By

acting as a third-party expert to provide independent technical analysis in disputes/mediation/arbitration/court actions, forensic geoscientists have assisted in finding "common ground", win-win solutions, and/or alternative approaches when rock, soil or water is a significant issue.

\section{Case examples where forensic geoscience delivers to the Criminal Justice System}

\subsection{Trace evidence}

Forensic geology supports many different types of criminal investigations. From assistance during a search investigation, collecting accurate information (e.g. "Dirt on shoes can often tell us more about where the wearer of those shoes had last been than toilsome inquiries"; Hans Gross, 1893); and locating where an offender had committed a crime, the discipline covers a wide range of potential applications.

Many examples of the application of forensic geology, which are allowed to be discussed openly, are presented in the works by Raymond Murray, one of the original scientists who developed this field (Murray and Tedrow, 1975 and 1992; Murray, 2004). Examples are given of a vehicle accident involving a pedestrian, where the offender drove off, with soil which had been deposited on the road at the point of impact with the victim, that had fallen from beneath the fender on the vehicle, and used to locate the car and driver. Hydrocarbon deposits found on the victim were also compared with hydrocarbons located under the vehicle, which also provided supporting evidence of contact. Soil found on clothing of a suspected rapist was used to place the suspect at the crime scene and to eliminate the suspect's alibi; small deposits of coal in the soil sample recovered from the trouser cuffs of the suspect, provided additional evidence when historical aerial photographs showed that coal was stored at the location of the rape.

Following on from the work of Ray Murray, publications presented further examples, such as the comparison of questioned trace evidence with potential source material involving a range of materials and tools such as clothing, footwear, footprints and stolen items such as a safety deposit box (e.g. Bull et al., 2006; Procter et al., 2019; Stam, 2003; Testoni et al., 2019). A wide variety of methods have been used for the sample analysis, including inorganic (e.g. Newell et al., 2012), organic, diatoms (Cameron, 2004) or a combination approach (Dawson and Hillier, 2012; Pye et al., 2005; Pye, 2007;

Ritz et al., 2009), with ongoing improvements being developed all the time (e.g. Ruffell and Sandiford, 2006). Spades and vehicles are also very good potential sources of evidence (Melo et al., 2019). A range of earth materials have been characterised in a forensic manner, including concrete (Martin, 2016), lead (Bond et al., 2013), gold (Roberts, 2016), nickel (Roelofse and Horstmann, 2008), zinc ingots (Salvador et al., 2019) and glass (Seyfang, 2015). 


\subsection{Search}

Geoscientists have identified the location of buried objects, such as chemical drums, storage tanks, vehicles, waste disposal trenches, bodies, drugs, precious metals and weapons, in addition to human bodies (Ruffell and McKinley, 2008; Pringle et al. 2012; Donnelly et al., 2019). Identifying the geological characteristics of rocks, used as weapons, has also led to the source location (provenance) of the rocks to be identified (Pirrie et al. 2019). Soil and other geological materials found on murder victims have been used to determine the location of the murder, in particular when the murder occurred in one location and the body had been moved to another location (Proctor et al. 2019). In addition, through the use of measurements of water currents, forensic geologists have located bodies and objects thrown into water and have also determined where the discovered body or object originally entered the water (Murray and Tedrow, 1975). Geophysical techniques have been successfully used in the search and recovery of human remains in water (e.g. Parker et al., 2010; Ruffell et al., 2017) and on land (Pringle et al., 2012). Other examples from across the world are reported in Dick et al. (2014), Fernandez-Alvarez et al. (2016), Molina et al. (2020), Nobes (2000), Novo et al. (2011), Pringle et al. (2010), Ruffell et al. (2014), Ruffell (2005), Wisniewski et al. (2019). Of particular ethical importance is the experimentation in relation to human biomarkers, and the use of human bodies in the identification of decomposition products and in the estimation of time after death. Human remains should be treated with dignity and respect and emphasise the responsibility of all stakeholders, including the forensic geologist, to ensure appropriate care for human remains (Squires et al., 2019).

\subsection{Environmental crime}

Forensic geology can be useful in the characterisation of illegal environmental deposits such as toxic waste and environmental contaminants (e.g. Ruffell et al., 2018) and can help track where materials were transported (e.g. Ruffell and Dawson, 2009). Sediment analysis by a geologist has led to the identification of the parties responsible for water pollution and adverse impacts on fisheries and soil erosion from construction activities, which was shown to have caused excessive lake sedimentation (Murray and Tedrow, 1992). In addition, through analysing the composition of a "gravel road" a forensic geologist showed how the road construction had influenced a vehicle accident (pers. comm.), and magnetic susceptibility analysis to determine the origin of soil dumped on a motorway that caused a fatal accident in China (Manrong et al., 2009).

\subsection{Wildlife crime}

Geophysical techniques have been applied in the context of wildlife crime (Wisniewski et al., 2019). In addition, illegal wildlife trade and wildlife crimes such as dog fighting and badger baiting have been solved through soil and geological materials adhering to items such as dog collars and tools (Morgan et al., 2006). Soil adhering to archaeological remains have been analysed and evidence led to a conclusion of exclusion as having come from a find site, leading to a rejection of a claim to treasure trove(pers. comm.).

\subsection{Civil context}

The analysis of site-specific excavation actions and geologic conditions have uncovered evidence that determined the party responsible for personal injury resulting from an excavation collapse, and 
evaluating the possible cause of a sewer tunnel explosion during construction: a forensic geologist showed that the cause was from human activities and that the explosive conditions were known and avoidable prior to construction of the tunnel (Murray and Tedrow, 1992). Evaluation of groundwater hydrology has also been used to show how retention of a pond caused increased flooding in a property cellar. In this case, a forensic geologist provided evidence that showed the extent of property damage, resulting from repeated flooding of a drain that had been dammed deliberately by a riparian owner to damage another riparian owner up stream. Also, based on chemical concentrations in the soil and groundwater, a forensic geologist calculated the original chemical concentrations to which workers were exposed to in the past (Murray and Tedrow, 1992).

\section{Consideration of potential malpractice}

In all of the many and varied applications of forensic geology outlined above, the possibility of malpractice exists. Malpractice can occur whenever a forensic geologist neglects to provide appropriate analysis, evaluation, and communication, omits to take an appropriate action, or gives substandard advice that causes loss of funds, harm, injury, or ultimately death. The malpractice or negligence normally involves an error, which can be accidental or deliberately. For example, this could be in soil or rock sampling, sample handling, analysis, evaluation, interpretation or in the presentation (or non-disclosure) of findings and bias.

An example of bad practice in forensic geology was recognised in a murder case, which occurred in Italy, where at the beginning of the trial, the soil traces were considered the most conclusive evidence to demonstrate the guilt of the victim's husband (Di Maggio and Barone, 2018). The Prosecution proposed that the husband killed his wife at home and subsequently brought her to the stream where the victim was found; and suggested that he denuded the body and brought back the clothes to his home to fabricate her leaving voluntarily. According to the prosecution, if the mud traces from the victim's trousers were comparable with the mud from the stream and were not comparable with the soil from the home garden, the hypothetical crime narrative could be confirmed. The Prosecution's technical Advisor (who was not a specialist in forensic geology techniques) stated that the mud from the victim's trousers "matched" the soil from the stream and was substantially different from the soil from the garden at the home address. However, several issues regarding the soil samples were not considered by the Court and Prosecution, and these were highlighted by the Counsel for the Defence during the cross-examination phase. In particular, the Counsel for the Defence, assisted by an expert in Forensic Geological techniques, demonstrated to the Court the problems associated with the comparison of the soil samples and the resultant limitations on their evidential value. In particular, the Prosecution Technical Advisor did not perform a robust examination of the crime scenes, the subsequent soil gathering and their preservation was inadequate, did not follow the national and international guidelines on Judicial Site Survey, and performed arbitrary analysis procedures that were not supported by previous laboratory research and published scientific peer-reviewed references. Thanks to those ethical issues brought to light by the Defence expert, in the judgement at First Instance the soil traces were declassed from evidence to the category of a clue. In the judgement of the Court of Appeal they were definitively considered 'not probative' and thus were not useful for the formulation of the verdict (Di Maggio and Barone, 2018). 
An example of bad practice, from a related discipline, forensic chemistry, was that of Regina $v$ Barry George, firstly found guilty of the murder of Jill Dando in London, UK. A singular small speck of gunpowder residue found in Barry George's pockets - which was later thrown out as being unreliable evidence - was the only non-circumstantial evidence used to convict him in 2000. During his retrial in 2008, the gunpowder residue evidence was ruled inadmissible by the judge after he was told that although it was the same type found on Dando's body, it could have come from any source. Such issues of over interpretation of a single particle also apply to forensic geology and must not be practiced by a forensic geologist. The wider context comparison (i.e. even if two samples share the same characteristics, where else could the questioned sample have come from?) has on occasion been omitted from forensic evaluation, potentially leading to false interpretation. Robertson (2009) disputed the use of the term 'match' for this very reason.

The standards and regulations for malpractice can differ between jurisdictions and between countries. In Italy, the Criminal Code envisages provisions for those expert witnesses who are suspected to be negligent or false witnesses. Previously in UK law it was not possible for an expert to be sued, but expert witnesses are no longer immune from being sued, see Jones v Kaney (2011). In this case, the Supreme Court ruled that an expert giving advice in the course of litigation is no longer immune if they act with negligence. This case overturned a long-established principle that expert witnesses should be protected from legal action on the basis of public policy. The right to a fair trial under Article 6 (UK Public General Acts 1998 c. 42) entitles an individual, whose position in civil proceedings has been compromised by negligent advice, to take action against that expert to be compensated for the damage received. In the English and Welsh jurisdiction, the Civil, Criminal and Family Procedure Rule, Practice Directions and the Guidance in English law all have requirements, which must be followed by the forensic geoscientist. In particular, certain declarations and statements must be included in the Expert's reports. For criminal cases, see Part 19 of the Criminal Procedure Rules 2015, as amended in 2020. Section 19.2 (of the Part 19 of the Criminal Procedure Rules) describes the expert's duty to the court; 19.3 the introduction of the expert evidence; 19.4 the content; 19.5 informed of service of report; 19.5 prehearing discussion of expert evidence; 19.7 single joint expert rules; and 19.8 instructions to a single joint expert, with 19.9 describing the Courts power to vary requirements under the Part. Although these are only directly applicable to England and Wales, they are a useful guide, especially on content (rule 19.4 in particular) (Dawson, Parratt and Auchie, 2019).

\section{Role for Geoethics}

There is an urgent need to improve the ethical framework and approaches for the forensic geology profession to minimise the possibility of malpractice, whether deliberate or not - for the protection of the individual scientist, the accused, the victim, the courts and for the benefit of civic society. For this reason, the IUGS Initiative on Forensic Geology (IUGS-IFG), jointly with the International Association for Promoting Geoethics (IAPG), deemed it necessary to consider the production of a White Paper on Geoethics in Forensic Geology, illustrating ethical issues that should be taken in account by the geological experts who are involved in forensic science.

Ethics has a clear purpose, and aims to clarify, for a given set of circumstances, how principles and values should inform appropriate action, considering the consequences of such action. Its function is 
to offer guiding principles to people when they need to make a choice, by providing a framework of reference values, shared by the social group to which they belong, that can lead to good, or to what is most useful or acceptable to the individual or society (Peppoloni and Di Capua, 2018). Geoethics is a new and rapidly emerging field within geoscience research and practice, which promotes an ethical approach, an ethical way of thinking and a sound way of practicing the geosciences, within the wider context of the social role that geoscientists can play while interacting with colleagues, professional communities, society and the Earth system (Peppoloni et al., 2019). There is a need for practitioners in forensic geology to ensure compliance with appropriate ethical standards in their work, in order to protect themselves, their workplace, their profession, the wider community, customers, and the environment. Geoethics has a fundamental role to play in shaping culture and behavioural reference values founded in scientific experience and knowledge (Peppoloni and Di Capua, 2016) and thus its social value will be demonstrated, furthering its intellectual and practical credibility. For these reasons, geoethics applied to forensic geology is crucial to assure scientific rigour and reliability for best practices.

The main aim of this draft White Paper proposal is to raise ethical issues of forensic geoscience, help fill the ethical gap and plan to define ethical values in the applications and best practise of Forensic Geology across the world.

\subsection{Geoethics in the context of Forensic Geology}

Given the importance of Forensic Geology in protecting communities and the environment, forensic intelligence and evidence must be managed in a highly ethical manner at all times. This starts at the first response to a call to attend a crime scene, through to selecting the most appropriate sampling scheme (see McKinley \& Ruffell, 2007; Pye et al. 2015), to the point of presenting evidence in court and any associated interactions thereafter, including that with the press. Applying geoethical values to forensic geology is of supreme importance, since it can have a direct impact on determining the fates of those involved in a criminal case: from the victim, victim's family and friends, through to the suspect as well as the general public.

Although forensic evidence can have great value in identifying and clarifying different aspects of a crime, and assisting investigators to hypothesise what happened, negligence and malpractices associated with this are always possible due to the human fallibility, negligence or in extreme cases, intentional misbehaviour. Each step in the whole process of the forensic investigation requires the highest level of professionalism, attention to detail, honesty, prudence and wisdom. For example, uncertainty about data is a delicate aspect, since errors must be minimized to help establish the truth, while also retaining transparency and clarity (McKinley, 2013).

Geoscientists are asked to assume the responsibility of using their knowledge for the benefit of society. The actions and choices that they make are submitted to the judgment of their colleagues (scientifically and technically) and society (in terms of their wider impacts and implications). Taking responsibility therefore means being answerable for their chosen actions, because of the professional competence to address the question raised. The necessity to develop a framework of reference ethical values for this specific field of geosciences is required. Moreover, that framework should be universal and applicable under all jurisdictions, because it refers to values that belong to science being 
conducted everywhere in the world and, as a consequence, to humankind. Geoethics can be useful to help trace an ethical path for this discipline, by orienting forensic geoscientists towards becoming more aware of and integrating ethical considerations into the whole practice of their profession.

\subsection{Ethical issues in Forensic Geology}

The main ethical issues in Forensic Geology can be considered as providing a platform to facilitate the following:

1. The competence of the geoscientist on different levels of interaction (individual, with colleagues, with clients, with the environment, with media, with society);

2. The context of the duties of the expert in Forensic Geology (role, accreditation, training and education, trust, maintaining the highest standards of professional conduct, recognising, and dealing with potential bias, be uninfluenced by motives of profit);

3. The ethical aspect in carrying out Forensic Geology activities (crime scene investigation, advise on sampling, uncertainty, evaluation, and interpretation of data);

4. The ethical aspects in communicating geoscience, from discussing case questions to the presentation of evidence (legal context, legal responsibilities, disclosure, testimony and reports, presentation of evidence, interaction with the media).

5. The ethical considerations for appropriate training, education, and legacy for future generations.

Fostering excellence in Forensic Geology is founded on practitioners becoming more aware of ethical and social implications in their work and of their responsibilities towards their professional community and society as a whole. For the scientific community the penalty for failure if things go wrong may be that scientists are held legally liable for the consequences of their actions. However, other penalties for failure is a loss of credibility (both for the individual and collectively as the profession), failure of the scientific and cultural role of geoscientists to facilitate society in facing geological problems, and also a loss of rationale for being geoscientists (Peppoloni and Di Capua, 2018).

The forensic geoscientist's responsibility is initially with themselves, in conducting their work to the best of their ability. It is in pursuing excellence in science, applying the most appropriate methods and technologies in research and application, and following (and contributing to the development, production and communication of) best scientific and professional practice (e.g. Keaney et al., 2009; Donnelly et al., 2020). A forensic geoscientist should maintain high standards of intellectual honesty; verify sources of data and information; report findings and interpretations fully and objectively; consider evidence on both sides of the legal consideration; be objective and impartial; make clear any limitations or gaps in evidence, information and caveats; be honest about the limits of one's own knowledge and competence, and act within these limits; avoiding conflicts of interest wherever possible, and declare any potential conflicts of interest; and engaging in ongoing professional training and the continuous improvement of geoscience knowledge throughout one's career (Mayer, 2015).

The forensic geoscientist should assess their actions with respect to their working environment, colleagues and the wider profession. It is the individual scientist's responsibility to cooperate and treat colleagues honestly and fairly; to respect others' ideas, take part in fair debate and embrace a 
diversity of perspectives, expertise and methods; to foster mutual understanding, share information and data, and support the intellectual and professional development of others; to respect and acknowledge the intellectual property of others. The forensic geoscientist produces knowledge and designs solutions for the benefit of society and its component parts. It is the individual's responsibility to serve society as effectively as possible, in order to support its development and assure its safety.

Forensic geoscientists should always consider ongoing professional development and take part in training and skills development of fellow professionals, consider accreditation and the wider community, and participate in public engagement, awareness raising and educational activities. They should carefully communicate their knowledge to law enforcement, court practitioners, policy-makers and public bodies, and should seek to develop constructive and responsible interactions between academia and industry. They should never comment on innocence or guilt; that is the duty of the triers of fact. They should never discuss such matters in a public forum, with repercussions such as the risk of defamation charges being served on the scientist.

Forensic geoscientists have specialist knowledge, expertise, professional, and cultural sensibility which is essential to assist the criminal justice system and to also entrust these guiding principles to future generations. Given the importance of such responsibility, it is important to consider all of these perspectives on a regular basis and keep them at the forefront of the mind and under constant review.

Forensic Geology should pursue social justice in compliance with legal systems, making clear the value of the highest ideals on which civil coexistence between human beings is founded. In order to achieve this goal, the main areas to be developed within the discipline are: the competence of the scientist in Forensic Geology; best practices; duties of the expert in Forensic Geology; ethical aspects in Forensic Geology activities and ethical aspects in communicating geoscience evidence.

When developing a professional approach in Forensic Geology, it is proposed that the following practices be considered in terms of deciding upon the best approach to take:

1. Use of appropriate methods and/or combination of complementary methods and accreditation.

2. Localization and analysis of areas of interest.

3. Collection and recovery of evidence.

4. Examination of data; evaluation of data and the expression of strength of evidence.

5. Databases, background information, documentation, cartography.

6. Communicating forensic data, summarising evidence, and consideration of uncertainty and bias.

7. Relationships between the forensic geologist and individuals, groups such as the State, the Media and members of the Criminal Justice System.

\section{Conclusions}


The professional body to which geoscientists belong needs to be considered, as does the language adopted and how the culture varies from country to country and the legal jurisdiction (Dawson, Parratt and Auchie, 2019).

Protocols, professional discipline and attitude, both nationally and internationally laws and codes of practice need to be considered. In addition, questions such as what qualifications a forensic geologist should have, what training and experience is necessary and aspects such as validation and accreditation are important considerations and need to be debated. The way that geological evidence is presented in court, the significance of geological evidence, whether an exclusionary principal should be used, or which scales are applied to geological evidence also needs further discussion. This paper wants to raise the issue and should be considered as a starting point for the discussion around the adoption of geoethics in Forensic Geology.

Forensic geology represents one of the fundamental applications of geoethics. It is an example of how geoscientists can serve society and how important it is that they consider the ethics of everything they do from attending a crime scene to presenting evidence in court. In addition, the work of the forensic geologists can often be of particular media interest and as such the scientist can be thrust onto the world media stage. That exposure requires the utmost robust ethical behaviour of practitioners. Geoscientists working in the forensic field must have the topic of ethics foremost in their minds, at all times, aware that they are handling issues that require the maximum of attention and have a duty of care, and must uphold utmost confidentiality.

Any error which may occur in practicing Forensic Geology can have serious consequences for the individual, families, communities and of course individual liberties, and thus responsible behaviours must be adopted, based on high standard of ethics and professionalism (Peppoloni et al., 2015; Mogk, 2017). Honesty, integrity, respect, transparency, competence, and reliability are vital principals for the forensic geoscientist to adhere to. They must uphold at all times the dignity of the many individuals involved. To ensure that forensic geoscientists are empowered now and into the future, acting now to agree upon a white paper and adopting effective ethical codes in the profession is essential.

Now is the time to hold the necessary robust discussions on the ethical and social implications of Forensic Geology and their potential repercussions on societal justice. Forensic Geology has been shown to be a very useful tool, in search, trace evidence comparison and as part of evidence presented in court in many areas of application. However, as with any other tool, when in human hands, it presupposes responsibility in its application. Professionalism and honesty in Forensic Geology is crucial. The public must be reassured that geoscientists involved in assisting law enforcement have the highest scientific respectability, social credibility and community respect for their role to help pursue judicial truth.

\section{Acknowledgements}

The authors are grateful to IUGS for providing funding to IUGS Initiative on Forensic Geology, enabling discussion of this topic and cooperation between nations. The authors are extremely grateful to the anonymous reviewers for their very helpful comments on the manuscript. 


\section{References}

The Criminal Procedure Rules (2015). SI 2015/1490:

https://www.legislation.gov.uk/uksi/2015/1490/contents, updated: https://www.legislation.gov.uk/uksi/2020/32/introduction/made.

Bergslien, E. (2012). An introduction to Forensic Geoscience. Wiley-Blackwell Pubs., $2^{\text {nd }}$ edition, ISBN 978-1405160544.

Bond, J.W., Hainsworth, S.V., \& Lau, T.L. (2013). Lead theft - a study of the uniqueness of lead from church roofs. Journal of Forensic Sciences, 58, 1003-1007. https://doi.org/10.1111/15564029.12156.

Bull, P., Parker, A, \& Morgan, R., (2006). The forensic analysis of soils and sediment taken from the cast of a footprint. Forensic Science International, 162, 6-12. https://doi.org/10.1016/i.forsciint.2006.06.075.

Cameron, N.G. (2004). The use of diatom analysis in forensic geoscience. In: Pye, K. \& Croft, D.J. (eds.) Forensic Geoscience: Principles, Techniques \& Applications. Geological Society of London Special Publication, 232, 277-280. https://doi.org/10.1144/GSL.SP.2004.232.01.25.

Dawson, L.A., and Hillier, S. (2010). Measurement of soil characteristics for forensic applications. Surface and Interface Analysis, 42, 363-377. http://dx.doi.org/10.1002/sia.3315.

Dawson, L.A., Parratt, D., and Auchie D. (2019). The application of forensic soil science in case work and legal considerations. In: Francese S. (ed.). Emerging Technologies for the Analysis of Forensic Traces. Springer International Publishing, Switzerland, Chapter 17, 245-261. https://doi.org/10.1007/978-3-030-20542-3 17.

Donnelly, L.J. (2010). The role of geoforensics in policing \& law enforcement. Emergency Global, 1922. Retrived: http://facstaff.buffalostate.edu/bergslet/ForensicGeology/Papers/Donnelly2010.pdf.

Donnelly, L.J., Cassella J., Pirrie, D., Dawson, L., Blom, G., Davidson, A., Arnold, P., Harrison, M. and Hope, C. (2019). Analysis of soil following a police-led open area search and the recovery of a coldcase homicide grave. Geological Society, London, Special Publications, 492, 29 October 2019, https://doi.org/10.1144/SP492-2017-337.

Donnelly, L.J., Pirrie D., Harrison, M., Ruffell, A., \& Dawson L.A. (eds.) (In press). A guide to forensic geology. Geological Society, London, Special Publication 2020.

Di Capua, G. \& Peppoloni S. (2019). Defining geoethics. Website of the IAPG - International Association for Promoting Geoethics, http://www.geoethics.org/definition.

Di Maggio, R.M., and Barone P.M. (2018). Murder or fatal accident? Ethics and professionalism in managing forensic geology evidence. RFG 2018: Resources for Future Generations. Booklet of Abstracts, Canadian Institute of Mining, Metallurgy and Petroleum.

Di Maggio, R.M., and Barone P.M. (eds) (2017). Geoscientists at Crime Scene. A Companion to Forensic Geoscience. Soil Forensics, Springer, pp. 226, ISBN 978-3319580487.

Dick, H.C., Pringle, J.K., Sloane, B., Carver, J., Haffenden, A., Porter, S., Wisniewski, K., Roberts, D. and Cassidy, N.J. (2015). Detection and characterisation of Black Death burials by multi-proxy geophysical methods. Journal of Archaeological Science, 59, 132-141. https://doi.org/10.1016/i.jas.2015.04.010. 
Fernandez-Alvarez, J.-P., Rubio-Melendi, D., Martinez-Velasco, A., Pringle, J.K. and Aguilera, D. (2016). Discovery of a mass grave from the Spanish Civil War using GPR and forensic archaeology. Forensic Science International, 267, e10-e17. http://dx.doi.org/10.1016/i.forsciint.2016.05.040.

Gross, H. (1893). Handbuch für Untersuchungsrichter - Polizeibeamte, Gendarmen (In German).

Harrison, M. and Donnelly, L.J. (2009). Locating Concealed Homicide Victims: Developing the Role of Geoforensics. In Ritz K., Dawson L., Miller D. (eds). Criminal and Environmental Soil Forensics. Springer Publishing, Dortrecht, The Netherlands, ISBN 978-1402092046, pp. 197-219. https://doi.org/10.1007/978-1-4020-9204-6 13.

Jones v Kaney (2011). UKSC 13. http://www.crownofficechambers.com/wpcontent/uploads/2017/01/jones $v$ kaney article.pdf.

Keaney, A., Ruffell A., and McKinley J. (2009). Geological Trace Evidence: Forensic and Legal Perspectives. In: Ritz K., Dawson L., and Miller D. (eds). Criminal and Environmental Soil Forensics. Springer, Dordrecht, ISBN 978-1402092046, pp. 231-237. https://doi.org/10.1007/978-1-40209204-6 14.

Larson, D.O., Vass, A.A. and Wise, M. (2011). Advanced scientific methods and procedures in the forensic investigation of clandestine graves. Journal of Contemporary Criminal Justice 27, 149-182. https://doi.org/10.1177/1043986211405885.

McKinley, J. and Ruffell, A. (2007). Contemporaneous spatial sampling at scenes of crime: advantages and disadvantages. Forensic Science International, 172, 196-202. https://doi.org/10.1016/i.forsciint.2006.09.006.

McKinley, J.M. (2013). How useful are databases in environmental and criminal forensics? Geological Society of London, Special Publication, 384, 109-119. http://dx.doi.org/10.1144/SP384.9.

Manrong, C., Yu, L., Niu, X. and Chen, B. (2009). Application of environmental magnetism on crime detection in a highway traffic accident from Yangzhou to Guazhou, Jiangsu Province, China. Forensic Science International, 187, 29-33. https://doi.org/10.1016/i.forsciint.2009.02.012.

Martin, D.C., Dabbs, G.R., Roberts, L.G., Cleary, M.K. (2016). The Stone Cold Truth: The Effect of Concrete Encasement on the Rate and Pattern of Soft Tissue Decomposition. Journal of Forensic Sciences, 61(2), 302-308. https://doi.org/10.1111/1556-4029.12970.

Mayer, T. (2015). Research Integrity: The Bedrock of the Geosciences. In: Wyss M. and Peppoloni S. (Eds.). Geoethics: Ethical Challenges and Case Studies in Earth Sciences. 450 p., Elsevier, Waltham, Massachusetts, ISBN 978-0127999357. https://doi.org/10.1016/B978-0-12-799935-7.00007-1.

Melo, V.F., Testoni, S.A., Dawson, L.A., de Lara, A.G., and da Silvia Salvador, F., (2019) Can analysis of a small clod of soil help to solve a murder case?. Science and Justice, 59, 667-677. https://doi.org/10.1016/i.scijus.2019.06.008.

Mogk, D. (2017). Geoethics and Professionalism: The Responsible Conduct of Scientists. In: Peppoloni S., Bobrowsky P.T., Di Capua G. and Cronin V.S. (Eds). Geoethics: at the heart of all geosciences. Annals of Geophysics, Vol. 60, Fast Track 7, https://doi.org/10.4401/ag-7584.

Molina, C.M., Wisniewski, K.D., Drake, J., Baena, A., Guatame, A. and Pringle, J.K. (2020). Testing application of GIS, forensic geomorphology and ERT to investigate suspected clandestine grave sites in Colombia, South America. Journal of Forensic Sciences, 65(1), 266-273. https://doi.org/10.1111/1556-4029.14168

Morgan, R., Wiltshire, P., Parker, A. and Bull, P.A. (2006). The role of forensic geoscience in wildlife crime detection. Forensic Science International, 162, 152-162. https://doi.org/10.1016/j.forsciint.2006.06.045. 
Murray, R.C. and Tedrow, J.C.F. (1975). Forensic Geology: Earth Sciences and Criminal Investigations. Rutgers University Press, New York, 217 pp. ISBN 978-0813507941.

Murray, R.C., and Tedrow, J.C.F. (1992). Forensic Geology. Upper Saddle River, New Jersey: Prentice Hall, 203 pp. ISBN 978-0133274530.

Murray, R.C. (2004). Evidence from the Earth: Forensic Geology and Criminal Investigation. Mountain Press, 226 pp. ISBN 978-0878424986.

Newell, A.J. Morgan, RM., Griffin, L.D., Bull, P.A., Marshall, J.R., and Graham, G. (2012). Automated texture recognition of quartz sand grains for forensic applications. Journal of Forensic Sciences, 57(5), 1285-1289. https://doi.org/10.1111/j.1556-4029.2012.02126.x.

Nobes, D.C. (2000) The Search for "Yvonne": A case example of the delineation of a grave using nearsurface geophysical methods. Journal of Forensic Sciences, 45, 715-721. https://doi.org/10.1520/JFS14756J.

Novo, A., Lorenzo, H., Ria, F. and Solla, M. (2011). 3D GPR in forensics: finding a clandestine grave in a mountainous environment. Forensic Science International, 204, 134-138. https://doi.org/10.1016/i.forsciint.2010.05.019.

Parker, R., Ruffell, A., Hughes, D. an Pringle, J. (2010). Geophysics and the search of freshwater bodies: a review. Science \& Justice, 50, 141-149. https://doi.org/10.1016/j.scijus.2009.09.001.

Peppoloni, S., Bilham N., and Di Capua, G. (2019). Contemporary Geoethics Within the Geosciences. In Bohle M. (Ed.). Exploring Geoethics - Ethical Implications, Societal Contexts, and Professional Obligations of the Geosciences. Cham: Springer International Publishing, Chapter 2, pp. 25-70. https://doi.org/10.1007/978-3-030-12010-8 2.

Peppoloni, S., Bobrowsky, P., and Di Capua, G. (2015). Geoethics: A Challenge for Research Integrity in Geosciences. In Steneck N., Anderson M., Kleinert S., Mayer T. (Eds.). Integrity in the Global Research Arena, World Scientific, pp. 287-294. https://doi.org/10.1142/97898146323930035.

Peppoloni, S., and Di Capua, G. (2016). Geoethics: Ethical, social, and cultural values in geosciences research, practice, and education. In: Wessel G.R. and Greenberg J.K. (Eds.). Geoscience for the Public Good and Global Development: Toward a Sustainable Future. Geological Society of America, Special Paper 520, pp. 17-21, https://doi.org/10.1130/2016.2520(03).

Peppoloni, S. and Di Capua, G. (2018). Ethics. In: Bobrowsky P.T. and Marker B. (Eds.). Earth Sciences Series. Encyclopedia of Engineering Geology. Springer International Publishing. https://doi.org/10.1007/978-3-319-12127-7 115-1.

Pirrie, D., Pidduck, J., Crean, D.E., Nicholls, T.M., and Awbury, R.P. (2019). Identification and analysis of man-made geological product particles to aid forensic investigation of provenance in the built $\begin{array}{lllll}\text { environment. } \quad \text { Forensic Science } & 109974 .\end{array}$ https://doi.org/10.1016/j.forsciint.2019.109974.

Pringle, J.K., Ruffell, A., Jervis, J.R. Donnelly, L., McKinley, J., Hansen, J., Morgan, R., Pirrie, D. and Harrison, M. (2012). The use of geoscience methods for terrestrial forensic searches. Earth Science Reviews, 114(1-2), 108-123. http://dx.doi.org/10.1016/i.earscirev.2012.05.006

Pringle, J.K. and Jervis, J.R. (2010). Electrical resistivity survey to search for a recent clandestine burial of a homicide victim, UK. Forensic Science International, 202(1-3), e1-e7. http://dx.doi.org/10.1016/i.forsciint.2010.04.023.

Procter, F.A., Swindles, G.T. and Barlow, N. (2019). Examining the transfer of soils to clothing materials: Implications for forensic investigations. Forensic Science International, 305, 110030. https://doi.org/10.1016/j.forsciint.2019.110030. 
Pye, K. (2007) Geological and Soil Evidence: Forensic Applications. CRC Press, Taylor \& Francis Group, US, 360 pp. ISBN 978-0849331466.

Pye, K., Blott, S., Croft, D.J. and Carter, J.F. (2005). Forensic comparison of soil samples: assessment of small-scale spatial variability in elemental composition, carbon and nitrogen isotope ratios, colour, and particle size distribution. Journal of Forensic Sciences, vol. 163(1-2), pp. 59-80. https://doi.org/10.1016/i.forsciint.2005.11.008.

Ramsland, K. (2012). Locard's Vision: 100 years of crime labs.Forensic Examiner, 21(2), 60-62.

Ritz, K., Dawson, L.A., and Miller, D. (Eds.) (2009). Criminal and Environmental Soil Forensics. Springer Netherlands, XL + 519 pp. ISBN 978-1402092039.

Roelofse, F. and Horstmann, U.E. (2008). A case study on the application of isotope ratio mass spectrometry (IRMS) in determining the provenance of a rock used in an alleged nickel switching $\begin{array}{lllll}\text { incident. } & \text { Forensic }\end{array}$ https://doi.org/10.1016/i.forsciint.2007.03.001.

Roberts, R.J, Dixon, R.D., and Merkle, R.K.W., (2016). Distinguishing between legally and illegally produced gold in South Africa. Journal of Forensic Sciences, 61(S1), S230-S236. https://doi.org/10.1111/1556-4029.12886.

Robertson, J. (2009). "Soils Ain't Soils": Context and Issues Facing Soil Scientists in a Forensic World. In: Ritz K., Dawson L.A., and Miller D. (Eds). Criminal and Environmental Soil Forensics. Springer Netherlands, XL + 519 pp. ISBN 978-1402092039, pp. 3-12. https://doi.org/10.1007/978-1-40209204-61.

Ruffell, A. (2005). Searching for the IRA "disappeared": Ground Penetrating radar investigation of a churchyard burial site. Journal of Forensic Sciences, 50(6), 1430-1435. https://doi.org/10.1520/JFS2004156.

Ruffell, A. (2010). Forensic pedology, forensic geology, forensic geoscience, geoforensics and soil $\begin{array}{llll}\text { forensics. Forensic Science 202(1-3), International, } & \end{array}$ https://doi.org/10.1016/j.forsciint.2010.03.044.

Ruffell, A., and Dawson, L.A. (2009) Forensic geology in environmental crime: Illegal waste movement and burial in Northern Ireland. Environmental Forensics, 1, 208-213. https://doi.org/10.1080/15275920903140346.

Ruffell, A. and McKinley, J. (2005). Forensic geoscience: applications of geology, geomorphology and geophysics to criminal investigations. Earth Science Reviews, 69(3-4), 235-247. https://doi.org/10.1016/i.earscirev.2004.08.002.

Ruffell, A. and McKinley, J. (2008). Geoforensics. Wiley-Blackwell, Chichester, X+332 pp. ISBN 9780470057353.

Ruffell, A., Pringle, J.K. and Forbes, S. (2014). Search protocols for hidden forensic objects beneath floors and within walls. Forensic Science International, 237, 137-145. https://doi.org/10.1016/i.forsciint.2013.12.036.

Ruffell, A., Pringle, J.K., Cassella, J.P., Morgan, R., Ferguson, M., Heaton, V.G. and Hope, C. (2017). The use of geoscience methods for aquatic forensic searches. Earth Science Reviews, 171, 323-337. https://doi.org/10.1016/i.earscirev.2017.04.012.

Ruffell, A., Pringle, J.K., Graham, C., Langton, M. and Jones, G. (2018). Geophysical assessment of illegally buried toxic waste for a Legal Enquiry: A case study in Northern Ireland, UK. Environmental Forensics, 19(4), 239-252. https://doi.org/10.1080/15275922.2018.1519740. 
Ruffell, A. and Sandiford, A. (2006). Maximising trace soil evidence: An improved recovery method developed during investigation of a \$26 million bank robbery. Forensic Science International, 209(1-3), e1-e7. https://doi.org/10.1016/j.forsciint.2011.03.007.

Salvador, F. A. da Silva, Nogueira e Silva, M.P., Mascarenhas, R.O., and Rumbelsperger, A.M.B., (2019). The application of forensic geology to investigate the substitution of zinc ingots between China and Brazil. Geological Society, London, Special Publications, 492. https://doi.org/10.1144/SP492-2018-83.

Seyfang, K.E., Redman, KE., Popelka, R.S., and Kirkbride, K.P. (2015). Glass fragments from portable electronic devices: Implications for forensic examinations. Forensic Science International, 257, 442452. https://doi.org/10.1016/i.forsciint.2015.10.023.

Stam, M. (2003). Soil as significant evidence in a sexual assault/attempted homicide case. In: Pye, K. and Croft, D.J. (Eds.). Forensic Geoscience: Principles, Techniques \& Applications. Geological Society of London Special Publication, 232, 295. https://doi.org/10.1144/GSL.SP.2004.232.01.28.

Squires K., Errickson D., and Márquez-Grant N. (2019). Introduction. In: Squires K., Errickson D., Márquez-Grant N. (Eds.). Ethical Approaches to Human Remains. Springer, Cham. https://doi.org/10.1007/978-3-030-32926-6 1.

Testoni S.A., Melo, V.F., Dawson, L.A., Salvador F.A.S. and Prandel L.V. (2019). Evaluation of forensic soil traces from a crime scene: robbery of a safety deposit box in Brazil. Geological Society, London, Special Publications, 492. https://doi.org/10.1144/SP492-2019-35.

Wisniewski, K., Pringle, J.K., Allen, D. and Wilson, G. (2019). Wildlife crime: use of geoscience surveys and geophysics to assist badger sett investigations. Forensic Science International, 294, e11-e18. https://doi.org/10.1016/i.forsciint.2018.10.026.

Wisniewski, K.D., Cooper, N., Heaton, V.D., Hope, C., Pirrie, D. and Pringle, J.K. (2019). The search for "Fred": an unusual vertical burial no-body case. Journal of Forensic Sciences, 64(5), 1530-1539. https://doi.org/10.1111/1556-4029.14035. 